\title{
Depth, Temperature and Salinity Preferences of Common Fishes of the Scotian Shelf
}

\author{
J. S. Scott \\ Department of Fisheries and Oceans, Marine Fish Division \\ Biological Station, St. Andrews, New Brunswick, Canada EOG $2 \times 0$
}

\begin{abstract}
Data from research bottom-trawl surveys of the Scotian Shelf and the Bay of Fundy in the 1970-79 period are analyzed to present total and preferred ranges and means of depth, temperature and salinity for $31 \mathrm{common}$ fishes. Geographical variation in relation to preferences and to fish distributions is examined for selected groups of fishes. Niche diversity is exemplified in groups of related species.
\end{abstract}

\section{Introduction}

Since 1970, annual research bottom-trawl surveys have been carried out in summer (July) on the Scotian Shelf (Fig. 1). Each survey comprised about 150 fishing stations which were selected on a depth-stratified random design (Halliday and Kohler, MS 1971). At each station, bottom temperature, depth and salinity determinations were recorded, together with associated information on numbers and weights of fish species caught. It is possible, therefore, to determine the ranges of the recorded environmental parameters over which each species occurred. It is also possible to determine changes in number or weight of fish caught over specific ranges within the overall range of the parameters examined, and thus derive means and preferred ranges of the environmental factors which may determine the occurrence of bottom fishes in the wild.

Information on temperatures which fresh-water fish tolerate or prefer is readily available from both laboratory and field studies (Coutant, 1977), but similar information on marine fish and on salinities and depths at which various species occur is widely scattered in the literature and based on few observations, at least for the Northwest Atlantic (e.g. Bigelow and Schroeder, 1953; Leim and Scott, 1966). Temperature appears to be an important determinant of fish distribution (McLellan, 1954; Colton, 1972; Scott, 1976), and there are obvious relationships between fish distribution and bottom depth on the Scotian Shelf (Scott, 1976). Hachey (1942) showed that depth, temperature and salinity are correlated on the Shelf, and the data from the bottom-trawl surveys provide further information on the relationships between these environmental parameters. More important, from a fisheries viewpoint, the data also indicate species preferences for, and geographical variation in, potential environmental determinants which may be of value in locating and studying behavior of marine fish populations.

\section{Materials and Methods}

During the 1970-79 period, 1,369 trawling stations were occupied on the Scotian Shelf and in the Bay of Fundy (Fig. 2), using standard sampling procedures (Halliday and Kohler, MS 1971). For each station, the number of each fish species caught and, where possible, bottom depth, temperature and salinity were recorded. Available data for each of the 31 common fish species caught were processed to give the percent caught (a) at 10-fath (18-m) intervals to 99 fath (182 m), 100-149 fath (183-272 m), 150-199 fath (273-364 m) and $200+$ fath $(365+\mathrm{m})$ (Table 1$)$; (b) at $1^{\circ} \mathrm{C}$ temperature intervals; and (c) at 1 part per thousand salinity intervals. Depth of tow was determined by echo sounder (average depth of tow was used), bottom temperature by mechanical bathythermograph and reversing thermometer, and salinity by the titration method or with a conductivity salinometer.

Ranges over which fishes occurred are expressed as "total", "mean" (weighted), and "preferred" in the text. The "preferred" range was arbitrarily chosen by inspection as the range(s) in which the incidence was above $10 \%$. Mean values are given in parentheses after the overall ranges for each fish in the text and Table 2. Results are given for the Scotian Shelf as a whole (including the Bay of Fundy) and, for geographic comparison, by NAFO divisions (Fig. 1) but treating the Bay of Fundy as a separate entity of Div. $4 \mathrm{X}$.

No tows were made in less than 15 fath $(28 \mathrm{~m})$, and this depth is the shallowest limit identified. The nature of the bottom in depths over 100 fath $(183 \mathrm{~m})$ was such that the depth of tow frequently varied by more than 10 fath $(18 \mathrm{~m})$ during a single set, and data for these tows were grouped into 50 -fath $(92-\mathrm{m})$ intervals over the 100-199 fath (183-364 $\mathrm{m}$ ) depth range. Fish numbers were averaged in each group to give the $10-$ fath $(18-\mathrm{m})$ or 50 -fath $(92-\mathrm{m})$ interval value as appropriate. There 


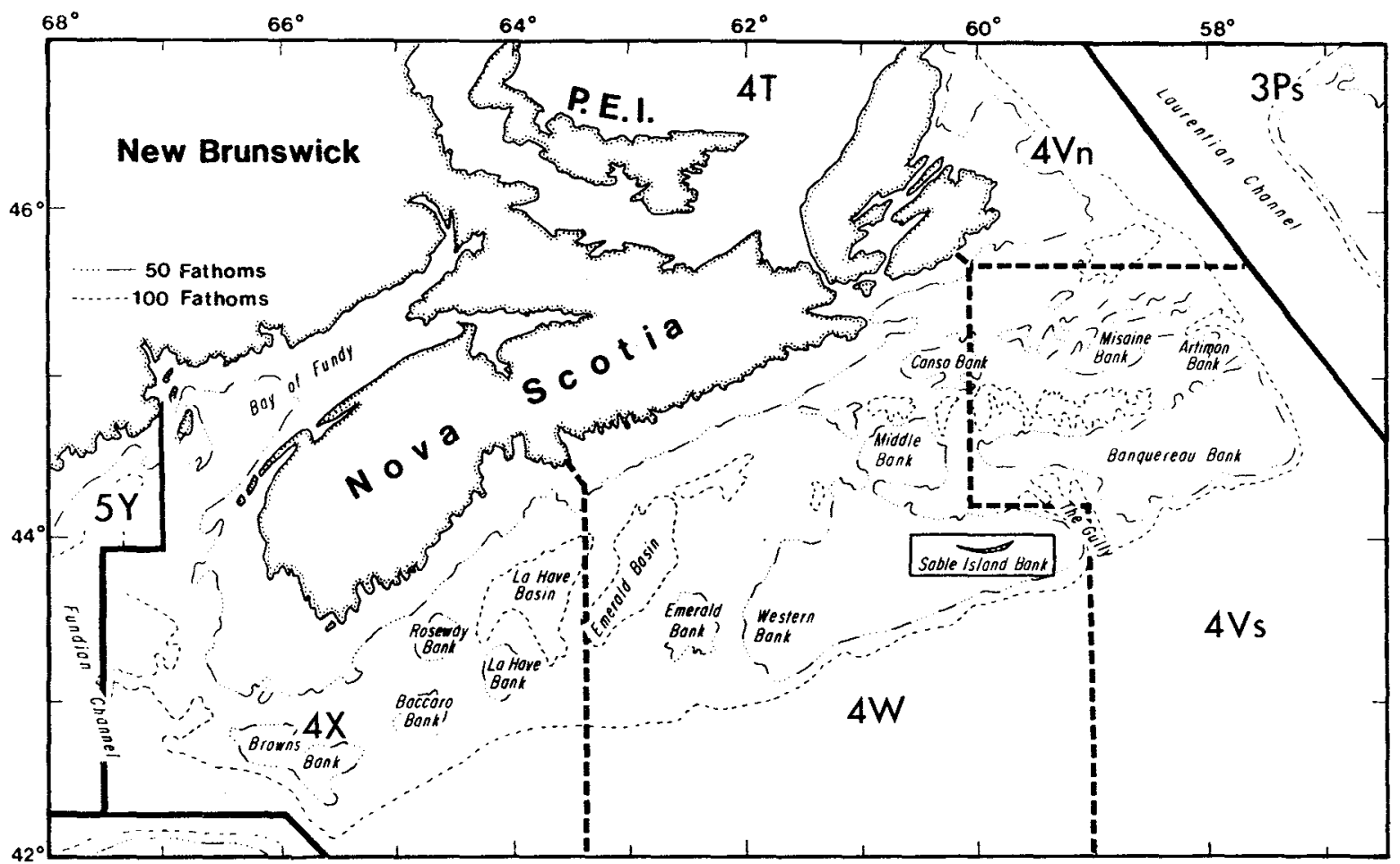

Fig. 1. Map of Scotian Shelf showing the NAFO divisions.

were relatively few tows in depths greater than 200 fath $(366 \mathrm{~m})$ and these were treated as a single group. Certain areas of rough bottom could not be fished, mainly along the coast and off Southwest Nova Scotia (Fig. 2), and consequently the species frequenting these areas may be under-represented in the data.

Abbreviations for total ranges used in the text are: $\mathrm{Dr}=$ total depth ranges in fathoms (fath), $\mathrm{Tr}=$ total temperature range in degrees Celsius $\left({ }^{\circ} \mathrm{C}\right)$, and $\mathrm{Sr}=$ total salinity range in parts per thousand $(\%$ ), each usually followed by the mean value in parentheses.

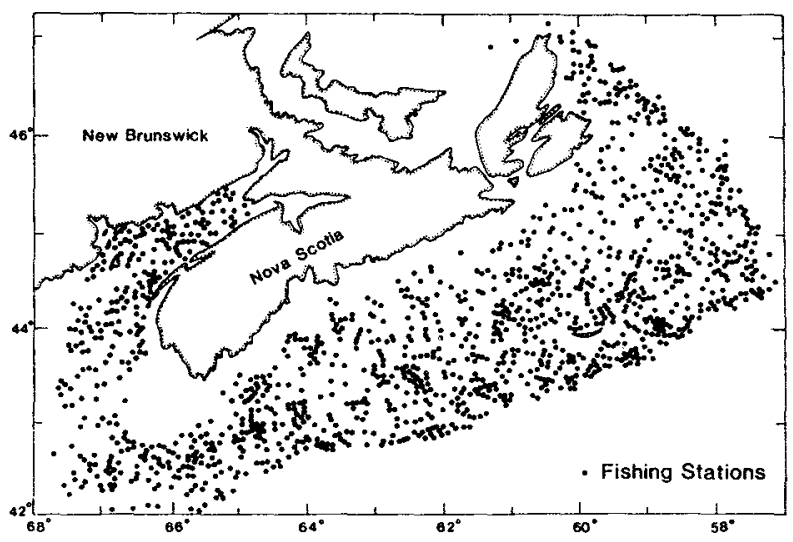

Fig. 2. Fishing stations occupied on the Scotian Shelf during research bottom-trawl surveys in summer, 1970-79.
Abbreviations for preferred ranges are: $D p=$ preferred depth; $T p=$ preferred temperature; and $S p=$ preferred salinity.

\section{Results}

For presentation in the text, the various species are arranged in alphabetical order by common English name followed by the scientific name, and, for comparison of the results in Fig. 3, they are arranged in order of increasing mean depth of occurrence.

American angler, Lophius americanus Valenciennes 1873

$$
\begin{array}{ll}
\mathrm{Dr}=15-200+(86.9) & \mathrm{Dp}=40-49,70-79 \\
\mathrm{Tr}=0-12(7.2) & \mathrm{Tp}=6-10 \\
\mathrm{Sr}=31-34(33.7) & \mathrm{Sp}=33-34
\end{array}
$$

Although the angler showed two ranges of preferred depth (40-49 and 70-79 fath), it was in fact fairly evenly distributed from 20 to 150 fath (Table 1). It is concentrated mainly in intermediate depths on the central part of the shelf and in deeper water on the continental slope where temperatures are fairly high. It is relatively rare on the northeastern and southwestern parts of the shelf where cool water persists (Scott, 1976). 
TABLE 1. Percent distribution by depth of common fishes on the Scotian Shelf from research vessel surveys, 1970-79.

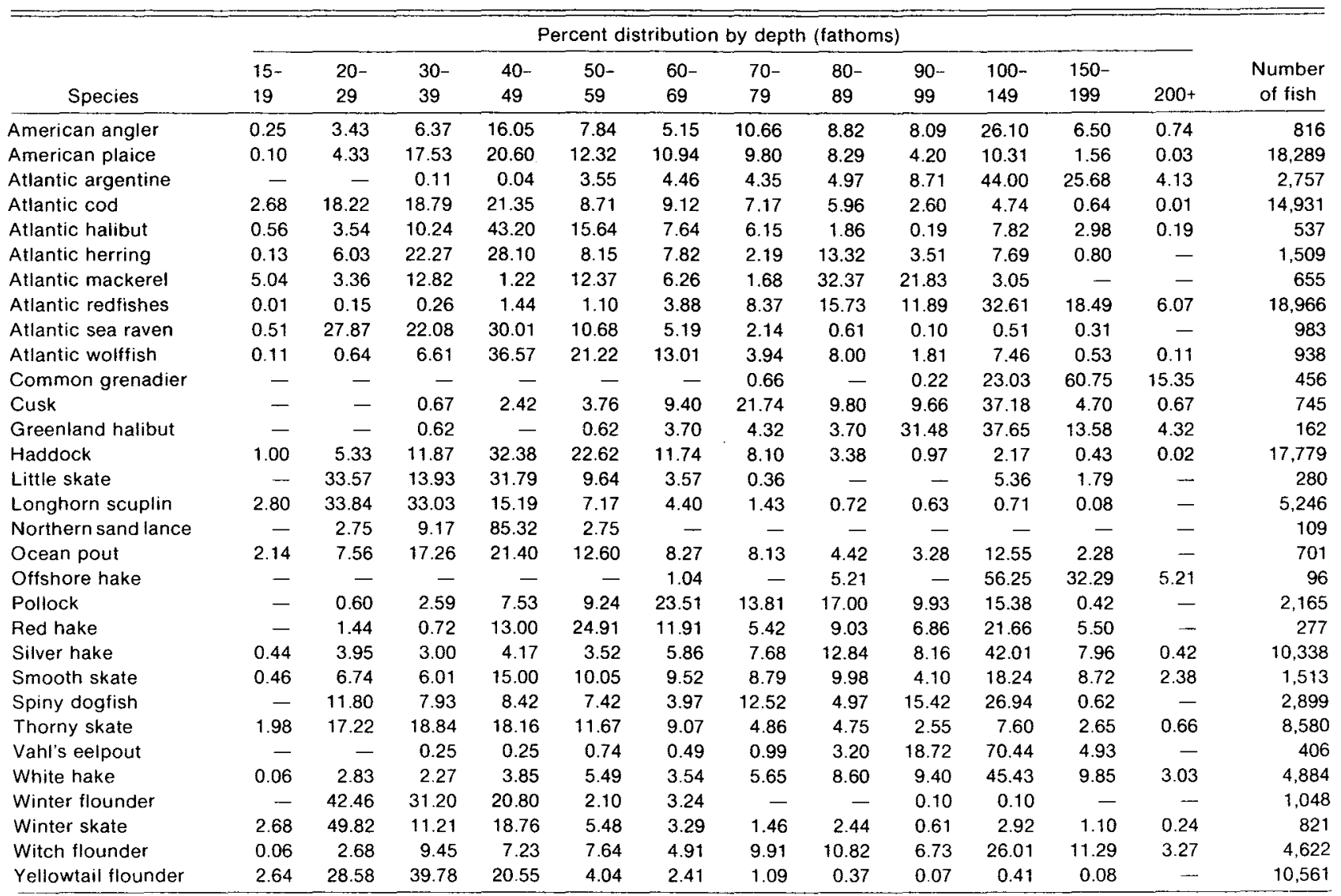

American plaice, Hippoglossoides platessoldes (Fabricius 1780)

$$
\begin{aligned}
\mathrm{Dr} & =15-200+(64.5) & \mathrm{Dp} & =30-70 \\
\mathrm{Tr} & =0-13(4.0) & \mathrm{Tp} & =1-4 \\
\mathrm{Sr} & =31-34(33.0) & \mathrm{Sp} & =33
\end{aligned}
$$

American plaice occupied the widest depth range exhibited by any species, with correspondingly wide temperature and salinity ranges. It showed erratic preferred depth distribution along the shelf (Table 2). Preferred ranges were fairly restricted in Div. $4 \mathrm{Vn}$ and $4 \mathrm{~W}$ (30-89 fath) but extensive in Div. 4Vs and $4 X(30-149$ fath), whereas it showed two preferred depths (30-49 and $90-99$ fath) in the Bay of Fundy. Mean depths were quite similar (61.4 to 68.5 fath) in the northeastern and central areas of the shelf but increased to 85.9 fath in Div. $4 X$ and decreased to 51.9 fath in the Bay of Fundy. Preferred and mean temperatures increased steadily from northeast to southwest (Table 2).

The wide depth, temperature and salinity ranges of American plaice conform with its extensive spatial distribution on the shelf (Scott, 1976), and the relatively low mean temperature of occurrence reflects the con- centration of the species in the cooler water of the northeastern part of the area.

Atlantic argentine, Argentina sllus Ascanius 1763

$$
\begin{array}{ll}
\mathrm{Dr}=30-200+(168.9) & \mathrm{Dp}=100-149 \\
\mathrm{Tr}=4-13(8.2) & \mathrm{Tp}=7-10 \\
\mathrm{Sr}=31-34(33.9) & \mathrm{Sp}=34
\end{array}
$$

Atlantic argentine was recorded from a wide range of depth but occurrence was negligible in depths less than 50 fath (Table 1). It showed no preferred depth at the 10 -fath interval level, but $44 \%$ of the catch was in 100-149 fath and $20 \%$ in 150-199 fath, confirming its preference for deep water. Preferred and mean depths, temperatures and salinities for argentine showed little variation throughout the area (Table 2) except that the mean salinity was inexplicably low in Div. $4 \mathrm{X}$.

The argentine is essentially a deep-water fish, concentrated on the continental slope and in deep-water basins on the shelf (Scott, 1976). The young are found in shallow water, however, but rarely less than 70 fath. The fish favours the warm, saline waters on the southwestern part of the shelf. 
TABLE 2. Preferred and mean values of depth, temperature and salinity, and percent of catch, by NAFO Division for major demersal fishes of the Scotian Shelf, from research surveys, 1970-79. (BF = Bay of Fundy.)

\begin{tabular}{|c|c|c|c|c|c|c|c|c|}
\hline \multirow[b]{2}{*}{ Species } & \multirow[b]{2}{*}{ Div. } & \multirow{2}{*}{$\begin{array}{c}\text { Percent } \\
\text { of } \\
\text { catch }\end{array}$} & \multicolumn{2}{|c|}{ Depth (fath) } & \multicolumn{2}{|c|}{ Temperature } & \multicolumn{2}{|c|}{ Salinity } \\
\hline & & & $D p$ & Mean & $T p$ & Mean & $S p$ & Mean \\
\hline \multicolumn{9}{|c|}{ Gadoids } \\
\hline \multirow[t]{5}{*}{ Atlantic cod } & $4 \mathrm{Vn}$ & 11.1 & - & $(66.0)$ & $3-4$ & $(3.2)$ & $31-34$ & $(33.0)$ \\
\hline & $4 \mathrm{Vs}$ & 21.7 & $20-49$ & $(56.3)$ & $2-4$ & $(3.4)$ & $32-34$ & (32.7) \\
\hline & $4 W$ & 42.1 & $20-49$ & $(39.6)$ & $3-7$ & $(4.9)$ & $32-34$ & $(32.7)$ \\
\hline & $4 X$ & 15.8 & $40-79$ & $(63.6)$ & $5-6$ & $(6.0)$ & $33-34$ & $(33.0)$ \\
\hline & $\mathrm{BF}$ & 9.3 & $30-59$ & $(55.0)$ & $7-8$ & $(7.8)$ & $32-34$ & $(32.6)$ \\
\hline \multirow[t]{5}{*}{ Haddock } & $4 \mathrm{Vn}$ & 0.4 & - & $(64.3)$ & $2-5$ & $(1.9)$ & $31-34$ & $(33.0)$ \\
\hline & $4 \mathrm{Vs}$ & 3.4 & $10-79$ & $(52.8)$ & $4-7$ & $(5.3)$ & $31-34$ & $(32.8)$ \\
\hline & $4 W$ & 31.0 & $20-69$ & $(49.6)$ & $4-10$ & $(6.7)$ & $32-34$ & (33.2) \\
\hline & $4 x$ & 57.2 & $40-69$ & $(56.0)$ & $4-8$ & $(6.4)$ & $32-34$ & $(33.2)$ \\
\hline & $B F$ & 8.0 & $30-49$ & $(48.7)$ & $7-9$ & $(7.9)$ & $32-34$ & $(32.5)$ \\
\hline \multirow[t]{5}{*}{ Pollock } & $4 \mathrm{Vn}$ & 0.4 & - & - & 4 & (4.9) & 33 & $(33.2)$ \\
\hline & $4 \mathrm{Vs}$ & 7.1 & $80-149$ & $(106.8)$ & $6-8$ & $(7.3)$ & 34 & (33.9) \\
\hline & $4 W$ & 20.1 & $40-149$ & $(74.5)$ & $9-10$ & $(8.6)$ & 34 & $(33.9)$ \\
\hline & $4 x$ & 58.0 & $60-149$ & $(81.3)$ & $6-9$ & (7.5) & $33-34$ & $(33.7)$ \\
\hline & $\mathrm{BF}$ & 14.4 & $40-79$ & $(62.1)$ & $6-8$ & $(7.2)$ & $32-34$ & $(33.1)$ \\
\hline \multirow[t]{5}{*}{ White hake } & $4 \mathrm{Vn}$ & 14.4 & $100-199$ & $(119.4)$ & $5-6$ & $(5.1)$ & 34 & $(33.9)$ \\
\hline & $4 \mathrm{Vs}$ & 18.0 & $100-149$ & $(124.3)$ & $5-7$ & $(6.4)$ & 34 & (33.8) \\
\hline & $4 W$ & 24.1 & $100-149$ & $(100.5)$ & $6-10$ & $(7.9)$ & 34 & $(33.9)$ \\
\hline & $4 x$ & 28.3 & 80-199 & $(122.7)$ & $6-9$ & $(7.6)$ & 34 & $(33.7)$ \\
\hline & $\mathrm{BF}$ & 15.2 & $\left.\begin{array}{c}20-59 \\
100-149\end{array}\right\}$ & $(70.7)$ & $7-10$ & $(8.1)$ & $31-34$ & $(32.6)$ \\
\hline \multirow[t]{5}{*}{ Silver hake } & $4 \mathrm{Vn}$ & 0.1 & - & - & - & - & $33-34$ & $(33.8)$ \\
\hline & $4 \mathrm{Vs}$ & 3.1 & - & $(78.1)$ & $2-6$ & $(4.8)$ & $32-34$ & $(33.2)$ \\
\hline & $4 W$ & 48.6 & $70-149$ & $(90.4)$ & $7-10$ & $(8.0)$ & $33-34$ & $(32.9)$ \\
\hline & $4 X$ & 45.9 & $80-199$ & $(114.8)$ & $8-10$ & $(8.4)$ & 34 & $(33.0)$ \\
\hline & $B F$ & 2.3 & $\left.\begin{array}{l}40-49 \\
90-149\end{array}\right\}$ & $(65.6)$ & $7-9$ & $(7.5)$ & $32-34$ & $(32.6)$ \\
\hline \multirow[t]{5}{*}{ Cusk } & $4 \mathrm{Vn}$ & - & - & - & - & - & - & - \\
\hline & $4 \mathrm{Vs}$ & 2.6 & $100-149$ & $(125.0)$ & $6-8$ & $(7.2)$ & 34 & $(34.0)$ \\
\hline & $4 W$ & 20.1 & $50-149$ & $(96.3)$ & $7-11$ & $(8.4)$ & 34 & $(34.0)$ \\
\hline & $4 X$ & 72.1 & $\left.\begin{array}{c}70-79 \\
100-149\end{array}\right\}$ & $(100.0)$ & $7-10$ & $(8.0)$ & $33-34$ & $(33.8)$ \\
\hline & $B F$ & 5.2 & $70-99$ & $(89.4)$ & $6-8$ & $(6.6)$ & 34 & (33.9) \\
\hline \multicolumn{9}{|c|}{ Flatfishes } \\
\hline \multirow[t]{5}{*}{ Atlantic halibut } & $4 \mathrm{Vn}$ & 0.2 & - & - & - & - & 33 & $(33.0)$ \\
\hline & $4 \mathrm{Vs}$ & 16.4 & $\left.\begin{array}{c}60-79 \\
100-149\end{array}\right\}$ & (98.5) & $5-8$ & $(6.1)$ & $33-34$ & $(33.8)$ \\
\hline & $4 W$ & 29.8 & $20-69$ & (57.9) & $4-10$ & $(6.5)$ & $32-34$ & $(34.0)$ \\
\hline & $4 x$ & 47.6 & $40-59$ & $(48.1)$ & $4-9$ & $(6.0)$ & $32-34$ & $(32.6)$ \\
\hline & $\mathrm{BF}$ & 6.0 & $30-49$ & $(38.7)$ & $7-9$ & $(8.0)$ & $32-33$ & $(32.3)$ \\
\hline \multirow[t]{5}{*}{ Yellowtail flounder } & $4 \mathrm{Vn}$ & 0.1 & - & - & - & - & $31-32$ & $(31.8)$ \\
\hline & $4 \mathrm{Vs}$ & 29.0 & $20-49$ & (34.9) & $2-6$ & $(3.4)$ & $32-33$ & (32.3) \\
\hline & $4 W$ & 65.5 & $20-49$ & (35.4) & $3-7$ & $(5.2)$ & $32-34$ & $(32.6)$ \\
\hline & $4 x$ & 5.1 & $30-59$ & $(48.0)$ & $5-9$ & $(5.5)$ & $33-34$ & (33.4) \\
\hline & $\mathrm{BF}$ & 0.3 & $30-39$ & $(35.0)$ & 9 & $(9.0)$ & $32-33$ & $(32.8)$ \\
\hline \multirow[t]{5}{*}{ American plaice } & $4 \vee n$ & 11.0 & $30-89$ & $(68.5)$ & $1-4$ & $(2.5)$ & $32-33$ & $(33.1)$ \\
\hline & $4 V_{s}$ & 40.2 & $30-149$ & $(61.4)$ & $1-4$ & $(3.2)$ & $32-34$ & $(32.8)$ \\
\hline & $4 W$ & 37.8 & $30-59$ & $(62.6)$ & $2-5$ & $(4.8)$ & $32-34$ & (33.1) \\
\hline & $4 X$ & 8.8 & $50-149$ & $(85.9)$ & $5-9$ & $(6.9)$ & $33-34$ & (33.5) \\
\hline & $B F$ & 2.2 & $\left.\begin{array}{l}30-49 \\
90-99\end{array}\right\}$ & $(51.9)$ & $6-7$ & $(7.1)$ & $32-34$ & (32.4) \\
\hline \multirow[t]{5}{*}{ Witch flounder } & $4 V n$ & 21.1 & $80-199$ & $(156.5)$ & $3-5$ & $(4.6)$ & $33-34$ & $(33.8)$ \\
\hline & $4 \mathrm{Vs}$ & 29.6 & $100-149$ & $(74.2)$ & $1-6$ & $(4.4)$ & $32-34$ & (33.4) \\
\hline & $4 W$ & 27.1 & $30-149$ & $(93.4)$ & $3-9$ & (6.2) & $33-34$ & (33.5) \\
\hline & $4 \mathrm{X}$ & 13.9 & $50-149$ & $(93.4)$ & $6-9$ & $(7.1)$ & $33-34$ & $(33.7)$ \\
\hline & $\mathrm{BF}$ & 8.3 & $\left.\begin{array}{l}30-49 \\
80-89\end{array}\right\}$ & (51.6) & $7-8$ & $(7.4)$ & $32-33$ & (32.4) \\
\hline
\end{tabular}


TABLE 2. (continued)

\begin{tabular}{|c|c|c|c|c|c|c|c|c|}
\hline \multirow[b]{2}{*}{ Species } & \multirow[b]{2}{*}{ Div. } & \multirow{2}{*}{$\begin{array}{c}\text { Percent } \\
\text { of } \\
\text { catch }\end{array}$} & \multicolumn{2}{|c|}{ Depth (fath) } & \multicolumn{2}{|c|}{ Temperature } & \multicolumn{2}{|c|}{ Salinity } \\
\hline & & & $\mathrm{Dp}$ & Mean & $T p$ & Mean & $\mathrm{Sp}$ & Mean \\
\hline \multicolumn{9}{|c|}{ Skates } \\
\hline \multirow[t]{5}{*}{ Thorny skate } & $4 \mathrm{Vn}$ & 6.9 & $50-89$ & $(84.1)$ & $1-4$ & $(3.0)$ & $32-34$ & (33.3) \\
\hline & $4 \mathrm{Vs}$ & 48.7 & $30-59$ & $(48.7)$ & $1-5$ & $(3.3)$ & $32-34$ & $(32.7)$ \\
\hline & $4 W$ & 27.2 & $20-49$ & $(52.3)$ & $2-6$ & (5.1) & $32-34$ & (32.9) \\
\hline & $4 X$ & 9.5 & $\left.\begin{array}{c}40-79 \\
100-149\end{array}\right\}$ & $(92.4)$ & $6-9$ & $(7.0)$ & $33-34$ & $(33.6)$ \\
\hline & $B F$ & 7.7 & $\left.\begin{array}{l}40-59 \\
90-99\end{array}\right\}$ & $(59.4)$ & $6-9$ & $(7.5)$ & $32-34$ & $(32.6)$ \\
\hline \multirow[t]{5}{*}{ Winter skate } & $4 V n$ & - & - & - & - & - & - & - \\
\hline & $4 \mathrm{Vs}$ & 20.5 & $20-29$ & $(35.3)$ & $4-9$ & $(6.0)$ & $32-34$ & $(32.2)$ \\
\hline & $4 W$ & 49.4 & $20-29$ & $(31.0)$ & $4-8$ & $(6.4)$ & $32-33$ & (32.3) \\
\hline & $4 x$ & 19.8 & $40-69$ & $(65.8)$ & $5-10$ & $(6.5)$ & $33-34$ & (33.3) \\
\hline & $B F$ & 10.3 & $20-49$ & $(40.8)$ & $8-11$ & $(8.4)$ & $31-33$ & $(31.7)$ \\
\hline \multicolumn{9}{|c|}{ Others } \\
\hline \multirow[t]{5}{*}{ Atlantic redfishes } & $4 \mathrm{Vn}$ & 13.0 & $80-199$ & (139.5) & $4-6$ & (4.6) & $33-34$ & (33.9) \\
\hline & $4 \mathrm{Vs}$ & 22.0 & $100-200+$ & $(126.0)$ & $1-7$ & $(4.7)$ & $33-34$ & $(33.8)$ \\
\hline & $4 W$ & 30.0 & $70-199$ & (112.7) & $6-9$ & (6.6) & $33-34$ & (33.8) \\
\hline & $4 x$ & 31.8 & $80-199$ & (116.0) & $6-9$ & $(7.7)$ & $33-34$ & (33.9) \\
\hline & $\mathrm{BF}$ & 3.2 & $\left.\begin{array}{l}40-69 \\
90-149\end{array}\right\}$ & $(85.4)$ & $6-8$ & $(7.0)$ & $32-33$ & (33.3) \\
\hline \multirow[t]{5}{*}{ Atlantic argentine } & $4 \mathrm{Vn}$ & - & - & - & - & - & 34 & $(34.0)$ \\
\hline & $4 \mathrm{Vs}$ & 7.3 & $100-199$ & $(136.4)$ & $7-9$ & (7.4) & 34 & $(34.0\rangle$ \\
\hline & $4 W$ & 26.9 & $100-199$ & $(124.5)$ & $6-10$ & $(8.3)$ & 34 & $(34.0)$ \\
\hline & $4 x$ & 65.7 & $100-199$ & $(129.8)$ & $7-9$ & $(8.2)$ & 34 & $(34.0)$ \\
\hline & $\mathrm{BF}$ & 0.1 & - & - & - & - & - & - \\
\hline
\end{tabular}

Atlantic cod, Gadus morhua Linnaeus 1758

$$
\begin{aligned}
\mathrm{Dr} & =15-200+(51.8) & \mathrm{Dp} & =20-49 \\
\mathrm{Tr} & =0-13(4.9) & \mathrm{Tp} & =3-7 \\
\mathrm{Sr} & =31-34(32.8) & \mathrm{Sp} & =32-34
\end{aligned}
$$

The mean depth of occurrence for cod on the Scotian Shelf was high in the northeastern, low in the central and high again in the southwestern area, although there was a decrease in the Bay of Fundy (Table 2). Preferred depth ranges followed the same general pattern. Preferred temperature ranges showed a general increase from northeast $\left(3^{\circ}\right.$ to $\left.4^{\circ} \mathrm{C}\right)$ to southwest $\left(7^{\circ}\right.$ to $\left.8^{\circ} \mathrm{C}\right)$, with the means increasing from $3.2^{\circ}$ to $7.8^{\circ} \mathrm{C}$.

Despite its wide depth distribution, the cod is essentially a shallow-water fish, at least in summer, when it is prevalent on the banks and in the Bay of Fundy, but major concentrations also occur along the northeastern slope of the shelf in the Laurentian Channel (Scott, 1976). Although cod prefers cooler water, its preferred temperature and salinity ranges are relatively wide, as is also the case for haddock, which commonly occurs with cod in research vessel catches on the central and southwestern parts of the shelf.
Atlantic halibut, Hippoglossus hippoglossus (Linnaeus 1758)

$$
\begin{aligned}
\mathrm{Dr} & =15-200+(59.3) & \mathrm{Dp} & =30-59 \\
\mathrm{Tr} & =1-13(6.4) & \mathrm{Tp} & =4-8 \\
\mathrm{Sr} & =31-34(33.2) & \mathrm{Sp} & =32-34
\end{aligned}
$$

Atlantic halibut occurred over the entire range of depths fished, but nearly $70 \%$ of the fish were caught in 30-59 fath (Table 1), although the mean depth was 59.3 fath. Preferred depths lay in the 20-69 fath range in Div. $4 W$ and $4 X$ and in the Bay of Fundy, but greater depths, 60-79 and 100-149 fath, were preferred in Div. 4Vs (Table 2). The mean depth decreased markedly along the shelf from 98.5 fath in the northeast to 38.7 fath in the Bay of Fundy. Preferred temperature varied little from Div. 4Vs to Div. $4 \mathrm{X}$, with fairly uniform mean temperatures $\left(6.0^{\circ}\right.$ to $\left.6.5^{\circ} \mathrm{C}\right)$, but the preferred range $\left(7^{\circ}\right.$ to $\left.9^{\circ} \mathrm{C}\right)$ and mean $\left(8.0^{\circ} \mathrm{C}\right)$ were considerably higher in the Bay of Fundy. Preferred and mean salinities varied considerably but not in step with depth and temperature, the highest mean values occurring in Div. $4 \mathrm{~W}$ and considerably lower values in Div. $4 \mathrm{X}$ and the Bay of Fundy.

The Atlantic halibut is widely distributed over the 
Scotian Shelf (Scott, 1976), mainly in shallow to intermediate depths on the central and southwestern areas of the shelf and along the northeastern slope, but avoiding the extreme conditions on the shallow northeastern part of the shelf and in the central basins. It is comparatively rare in research vessel catches.

\section{Atlantic herring, Clupea harengus Linnaeus 1758}

$$
\begin{aligned}
& \mathrm{Dr}=15-199(58.8) \\
& D p=30-49,80-89 \\
& \mathrm{Tr}=0-11(5.8) \\
& \mathrm{Sr}=31-34(33.0) \\
& T p=1,7-9 \\
& S p=32-34
\end{aligned}
$$

Both the preferred depths and temperatures for herring were bivalent, with about $50 \%$ of the catches in 30-49 fath depth range. Because of its pelagic behavior, herring is relatively rare in bottom-trawl catches, and the data are probably not truly representative of its occurrence on the Scotian Shelf.

Atlantic mackerel, Scomber scombrus Linnaeus 1758

$$
\begin{aligned}
& \text { Dr }=15-149(67.0) \quad D p=30-39,50-59,80-89 \\
& \mathrm{Tr}=0-11(7.2) \quad \mathrm{Tp}=2,7-10 \\
& \mathrm{Sr}=32-33(33.6) \quad \mathrm{Sp}=32,34
\end{aligned}
$$

Preferred depths for mackerel fell into three ranges, with indication of bivalence in preferred temperatures and salinities. These anomalies are probably due to the fact that, like herring, mackerel is largely pelagic, and neither its abundance, distribution nor environmental preferences are likely to be truly reflected in bottom-trawl catches.

Atlantic redfishes, Sebastes sp. (Linnaeus 1758)

$$
\begin{aligned}
\mathrm{Dr} & =15-200+(120.1) & \mathrm{Dp} & =80-99 \\
\mathrm{Tr} & =0-13(6.2) & \mathrm{Tp} & =5-9 \\
\mathrm{Sr} & =31-34(33.4) & \mathrm{Sp} & =33-34
\end{aligned}
$$

Redfish showed little change in preferred (70-200+ fath) or mean (116.0-139.5 fath) depths along the Scotian Shelf from Div. $4 \mathrm{Vn}$ to Div. $4 \mathrm{X}$, but the preferred range was bivalent (40-69 and 90-149 fath) in the Bay of Fundy with a corresponding lower mean of 85.4 fath (Table 2). The lower preferred range may be due to the mixed species problem in redfish or simply to concentrations of smaller redfish in shallow water. Preferred and mean temperatures increased steadily along the shelf from northeast to southwest with a decrease in the Bay of Fundy, but salinities showed little geographic variation.

Redfish is widely distributed in moderate to deep water along the edge of the Scotian Shelf from the
Laurentian Channel to the entrance of the Bay of Fundy, with major concentrations in the northeastern area (Scott, 1976). Shallow-water concentrations in the Bay of Fundy and on the shelf may be younger fish of the prevalent deepwater species or a separate species.

\section{Atlantic sea raven, Hemitripterus americanus (Gmelin 1789)}

$$
\begin{aligned}
\mathrm{Dr} & =15-199(40.9) & \mathrm{Dp} & =20-59 \\
\mathrm{Tr} & =2-12(6.9) & \mathrm{Tp} & =6-9 \\
\mathrm{Sr} & =31-34(32.4) & \mathrm{Sp} & =32-33
\end{aligned}
$$

The main concentrations of sea raven were found in warm shallow water on the central part of the shelf and in the Bay of Fundy, similar to ocean pout.

\section{Atlantic wolffish, Anarhichas lupus Linnaeus 1758}

$$
\begin{aligned}
\mathrm{Dr} & =15-200+(57.4) & \mathrm{Dp} & =40-69 \\
\mathrm{Tr} & =0-13(5.0) & \mathrm{Tp} & =3-6 \\
\mathrm{Sr} & =31-34(33.0) & \mathrm{Sp} & =32-34
\end{aligned}
$$

The Atlantic wolffish was widely distributed over the shelf, with major concentrations on the banks of the southwestern area. It was common but not abundant in the research vessel catches.

\section{Common grenadier, Nezumla balrdl (Goode and Bean} 1877)

$$
\begin{aligned}
\mathrm{Dr} & =70-200+(166.5) & \mathrm{Dp} & =150-200+ \\
\mathrm{Tr} & =4-13(6.0) & \mathrm{Tp} & =5-8 \\
\mathrm{Sr} & =31-34(33.9) & \mathrm{Sp} & =34
\end{aligned}
$$

Catch of this species were confined to deep water with $99 \%$ taken deeper than 100 fath (Table 1). It is distributed in comparatively warm, saline water on the slope of the shelf and ranges to depths of at least 1,255 fath (Bigelow and Schroeder, 1953). It is not usually found in the deep basins on the shelf (Scott, 1976).

\section{Cusk, Brosme brosme (Müller 1776)}

$$
\begin{aligned}
\mathrm{Dr} & =30-200+(99.4) & \mathrm{Dp} & =70-79 \\
\mathrm{Tr} & =2-12(8.0) & \mathrm{Tp} & =6-10 \\
\mathrm{Sr} & =32-34(33.8) & \mathrm{Sp} & =34
\end{aligned}
$$

Cusk was found mainly in depths between 40 and 199 fath (Table 1), the mean being 99.4 fath, and showed no definite trend in depth, temperature or salinity preference along the Scotian Shelf (Table 2). It is found mostly in warm water at intermediate depths 
on the southwestern part of the shelf and is virtually absent in the northeastern area except in the deep (warm) water along the slope (Scott, 1976). It favors rough bottom (Bigelow and Schroeder, 1953) and is therefore relatively rare and probably underrepresented in trawl catches.

Greenland halibut, Relnhardtius hippoglossoldes (Walbaum 1792)

$$
\begin{array}{rlrl}
\mathrm{Dr} & =30-200+(118.4) & \mathrm{Dp}=90-149 \\
\mathrm{Tr} & =1-7(3.5) & \mathrm{Tp}=1-5 \\
\mathrm{Sr} & =31-34(33.5) & \mathrm{Sp} & =33-34
\end{array}
$$

The depth range of this species was extensive but $87 \%$ of the catches were made in depths greater than 90 fath (Table 1), the preferred depth range being 90-149 fath. Greenland halibut is a northern species, uncommon on the Scotian Shelf but showing increasing abundance from Div. $4 X(1.3 \%)$ northeastward to Div. $4 \mathrm{Vn}(42.8 \%)$.

Haddock, Melanogrammus aeglefinus (Linnaeus 1758)

$$
\begin{array}{ll}
\text { Dr }=15-200+(53.7) & \mathrm{Dp}=30-69 \\
\mathrm{Tr}=1-13(6.5) & \mathrm{Tp}=4-8 \\
\mathrm{Sr}=31-34(33.1) & \mathrm{Sp}=32-34
\end{array}
$$

There was no evident trend in preferred depth range along the Scotian Shelf, but mean depth showed an erratic decrease from 64.3 fath in the northeastern to 48.7 fath in the southeastern areas (Table 2). Temperature preference showed a marked increase from a range of $2^{\circ}$ to $5^{\circ} \mathrm{C}$ in Div. $4 \mathrm{Vn}$ to $7^{\circ}$ to $9^{\circ} \mathrm{C}$ in the Bay of Fundy, but the ranges and mean levels (5.3-6.7) were fairly constant between the two extremes. Salinity preference showed little variation but tended to be higher in the central and southwestern areas (Div. $4 \mathrm{~W}$ and $4 X$ ) than elsewhere.

In spite of its wide range, haddock, like cod, is essentially restricted to shallow and intermediate depths, at least in summer. It is concentrated mainly on the central and southwestern parts of the shelf (Scott, 1976), but, with recent stock increase, it is extending its distribution northeastward and may reestablish the migratory fishery in the Gulf of St. Lawrence (Div. 4T) which thrived prior to the 1960's. It is commonly caught in the same depths as cod but prefers somewhat higher temperatures and salinities.

\section{Little skate, Raja erinacea Mitchill 1825}

$$
\begin{array}{ll}
\mathrm{Dr}=20-199(45.3) & \mathrm{Dp}=20-49 \\
\mathrm{Tr}=4-11(8.2) & \mathrm{Tp}=5-10 \\
\mathrm{Sr}=31-34(32.1) & \mathrm{Sp}=31-34
\end{array}
$$

This species is shown to have occurred in two depth ranges, 20-79 and 100-199 fath (Table 1) with a preferred depth range of 20-49 fath. The deeper range is doubtful and probably reflects confusion of identification with the winter skate, $R$. ocellata, as the little skate is regarded as a shallow-water species (Leim and Scott, 1966).

\section{Longhorn sculpin Myoxocephalus octodecemspino- sus (Mitchill 1815)}

$$
\begin{aligned}
& \mathrm{Dr}=15-199(37.4) \\
& \mathrm{Tr}=1-13(5.4) \\
& \mathrm{Sr}=31-34(32.4)
\end{aligned}
$$

$$
\begin{aligned}
& D p=20-49 \\
& T p=3-7 \\
& S p=32-33
\end{aligned}
$$

About $80 \%$ of catches of this species were in the preferred range of 20-49 fath (Table 1). It is usually concentrated in cool, shallow water on the northeastern part of the shelf and in the Bay of Fundy (Scott, 1976), commonly associated with winter skate and yellowtail flounder.

\section{Northern sand lance, Ammodytes dubius Reinhardt 1838}

$$
\begin{aligned}
& \mathrm{Dr}=20-59(43.3) \\
& \mathrm{Tr}=1-11(4.1) \\
& \mathrm{Sr}=32-34(32.9)
\end{aligned}
$$

$$
\begin{aligned}
& D p=40-49 \\
& T p=1,7 \\
& S p=32,34
\end{aligned}
$$

Sand lance was restricted to shallow water, with about $85 \%$ of the catches in the preferred depth range of 40-49 fath (Table 1). The temperature and salinity data are extremely erratic, reflecting the distribution of the fish which is probably controlled by depth and bottom-type factors rather than temperature (J. S. Scott, unpublished data).

Sand lance is found in localized concentrations in shallow water on most of the major banks of the Scotian Shelf where the bottom consists of sand or fine gravel. It has been taken on the shelf in depths as shallow as 8 fath and also in coastal waters of the Bay of Fundy, although the latter may be a separate species. The Scotian Shelf population remains in shallow water throughout the year irrespective of temperature (Scott, 1976).

\section{Ocean pout, Macrozoarces amerlcanus (Bloch and Schneider 1801)}

$$
\begin{array}{ll}
\text { Dr }=15-199(62.9) & \text { Dp }=30-59 \\
\operatorname{Tr}=0-11(6.8) & \text { Tp }=6-9 \\
\mathrm{Sr}=31-34(32.9) & \mathrm{Sp}=32-34
\end{array}
$$

This species occurred mainly on the central part of the Scotian Shelf and in the Bay of Fundy in shallow to 
moderate depths and relatively warm water (Scott, 1976). It is rarely found on the northeastern area of the shelf.

Offshore hake, Merluccius albidus (Mitchill 1818)

$$
\begin{array}{rlrl}
\text { Dr } & =60-200+(142.3) & & D p=>100 \\
\operatorname{Tr} & =5-10(8.1) & & \text { Tp }=5,8-10 \\
\mathrm{Sr} & =34 & \mathrm{Sp} & =34
\end{array}
$$

Offshore hake was caught over an extensive depth range, but over $90 \%$ of the catches were in depths greater than 100 fath (Table 1). Two preferred temperature ranges were evident $\left(5^{\circ}\right.$ and $8^{\circ}$ to $\left.10^{\circ} \mathrm{C}\right)$, but the lower one may be due to confusion of identification with silver hake, $M$. bilinearis.

Pollock, Pollachius virens (Linnaeus 1758)

$$
\begin{aligned}
\mathrm{Dr} & =20-199(79.0) & \mathrm{Dp} & =60-99 \\
\mathrm{Tr} & =2-12(7.6) & \mathrm{Tp} & =6-10 \\
\mathrm{Sr} & =31-34(33.7) & \mathrm{Sp} & =33-34
\end{aligned}
$$

The overall preferred depth range for pollock was quite broad, the mean depth of occurrence being greatest in Div. 4Vs and lowest in the Bay of Fundy (Table 2). Temperature preference was lowest in the extreme northwestern part of the region and relatively constant (range of means $7.2^{\circ}$ to $8.6^{\circ} \mathrm{C}$ ) over the remainder of the shelf. Salinities were consistently high (33-34\%) over the main part of the shelf (Div. $4 \mathrm{Vs}, 4 \mathrm{~W}$ and $4 \mathrm{X}$ ) and lower in Div. 4Vn and the Bay of Fundy.

The major pollock concentrations are generally confined to the central and southwestern parts of the shelf and the Bay of Fundy (Scott, 1976). The fish ranges widely through the water column. Trawl catches are generally in warm water of high salinity (Table 2), but, since the species also occurs in shallow coastal waters of low salinity, the research survey data are not fully representative of the ranges over which it occurs.

Red hake, Urophysis chuss (Walbaum 1792)

$$
\begin{aligned}
\mathrm{Dr} & =20-199(82.1) & \mathrm{Dp} & =40-69 \\
\mathrm{Tr} & =3-11(8.0) & \mathrm{Tp} & =5-10 \\
\mathrm{Sr} & =31-34(33.7) & \mathrm{Sp} & =33-34
\end{aligned}
$$

About $50 \%$ of the research vessel catches occurred in the preferred depth range of 40-69 fath (Table 1). The difficulty in separating red hake from white hake has resulted in some confusion relevant to the distribution of the species. Red hake tends to frequent shallow water areas on the southwestern part of the shelf, whereas mature white hake tends to be widely distributed in deep water, with major concentrations along the northeastern slope of the shelf in the Laurentian Channel (Scott, 1976).

\section{Silver hake, Merluccius bllinearis (Mitchill 1814)}

$$
\begin{aligned}
\mathrm{Dr} & =15-200+(101.4) & \mathrm{Dp} & =80-89 \\
\mathrm{Tr} & =1-13(8.1) & \mathrm{Tp} & =7-10 \\
\mathrm{Sr} & =31-34(33.8) & \mathrm{Sp} & =33-34
\end{aligned}
$$

Although silver hake occurred in all depth ranges examined with only a minor indication of preferred depth at 80-89 fath, its distribution was weighted towards deeper water (mean depth of 101.4 fath); $42 \%$ of the catches were made in 100-149 fath (Table 1). Preferred and mean depths tended to increase from northeast to southwest along the shelf with a bivalent range for the Bay of Fundy, including a shallow-water (40-49 fath) preference (Table 2). There was a parallel trend of increasing temperature along the shelf but salinity decreased.

Silver hake overwinters in deep water along the edge of the shelf and in the deep basins and then migrates onto the central and southwestern banks of the shelf to spawn. It tends to seek warm water and is therefore only sparsely distributed over the northeastern part of the shelf (Scott, 1976).

\section{Smooth skate, Raja senta Garman 1885}

$$
\begin{array}{rlrl}
\text { Dr } & =15-200+(84.1) & & D p=40-89 \\
\mathrm{Tr} & =0-13(5.9) & \mathrm{Tp} & =3-8 \\
\mathrm{Sr} & =31-34 & \mathrm{Sp} & =32-34
\end{array}
$$

Smooth skate is found mainly in intermediate depths on the edges of the banks on the shelf, in the Bay of Fundy, and along the northeastern slope in the Laurentian Channel (Scott, 1976). The percent occurrence at 10-fath intervals in the 40-89 fath range is so uniform that this is given as the preferred depth range although some values are below the 10\% level (Table 1).

\section{Spiny dogfish, Squalus acanthlas Linnaeus 1758}

$$
\begin{aligned}
\mathrm{Dr} & =20-199(78.9) & \mathrm{Dp} & =20-29,70-79,90-99 \\
\mathrm{Tr} & =3-11(8.0) & \mathrm{Tp} & =7-9 \\
\mathrm{Sr} & =31-34(33.2) & \mathrm{Sp} & =31-34
\end{aligned}
$$

Spiny dogfish was fairly evenly distributed throughout the indicated depth range with little indication of preferred depths (Table 1). It intrudes in summer into the Bay of Fundy and the Fundian Channel, and occasional large catches have been taken on the Scotian Shelf (Scott, 1976), always associated with 
warm water. Temperature appears to control its occurrence as indicated by its wide depth range and penetration into shallow low-salinity water of the Bay of Fundy.

Thorny skate, Raja radiata Donovan 1807

$$
\begin{array}{ll}
\mathrm{Dr}=15-200+(57.2) & \mathrm{Dp}=20-59 \\
\mathrm{Tr}=0-13(4.5) & \mathrm{Tp}=2-5 \\
\mathrm{Sr}=31-34(32.9) & \mathrm{Sp}=32-34
\end{array}
$$

Although the overall preferred depth range for thorny skate indicates relatively shallow water distribution, the preferred depth and salinity ranges on various areas of the shelf were erratic with no obvious trend. However, both the preferred temperature range and the mean increased steadily from northeast to southwest (Table 2). This species was possibly the most generally distributed of the fishes examined in relation to depth, temperature and salinity, although its preferred ranges shows a high degree of specificity.

Thorny skate is the most abundant of the skates found on the Scotian Shelf. Although it is widely distributed over the whole shelf and in the Bay of Fundy, concentrations are often found in cool shallow water on the northeastern part of the shelf (Scott, 1976).

Vahl's eelpout, Lycodes vahlil Reinhardt 1838

$$
\begin{array}{ll}
\mathrm{Dr}=30-199(118.8) & \mathrm{Dp}=90-149 \\
\mathrm{Tr}=1-8(2.2) & \mathrm{Tp}=1,4 \\
\mathrm{Sr}=32-34(33.0) & \mathrm{Sp}=33
\end{array}
$$

This eelpout occurred in cool deep water, being most common in the central and northeastern parts of the shelf where over $90 \%$ of the catches were recorded. The two distinct preferred temperatures are difficult to explain, as there was no similar bivalence in depth or salinity preferences.

\section{White hake, Urophycis tenuis (Mitchill 1815)}

$$
\begin{array}{ll}
\mathrm{Dr}=15-200+(113.6) & \mathrm{Dp}=80-199 \\
\mathrm{Tr}=0-13(7.1) & \mathrm{Tp}=5-9 \\
\mathrm{Sr}=31-34(33.7) & \mathrm{Sp}=33-34
\end{array}
$$

There was no identifiable preferred depth range at the $10 \%$ level for this species (Table 1 ), but it occurred persistently in depths of 80-199 fath in warm $\left(\geqslant 5^{\circ} \mathrm{C}\right)$ and saline $(\geqslant 33 \%$ ) water, where more than $60 \%$ of the catches were recorded. Preferred depth ranges showed little change along the shelf, but there was a shallow-water (20-59 fath) concentration in the Bay of Fundy (Table 2). Preferred and mean temperatures increased steadily from northeast to southwest along the shelf while preferred salinities decreased over the area.
White hake is widely distributed over the shelf and in the Bay of Fundy, with major concentrations in deep-water areas of the Fundian Channel, the shelf basins and along all slopes of the shelf (Scott, 1976).

Winter flounder, Psuedopleuronectes americanus (Walbaum 1792)

$$
\begin{array}{ll}
\mathrm{Dr}=20-149(34.4) & \mathrm{Dp}=20-49 \\
\mathrm{Tr}=2-12(7.5) & \mathrm{Tp}=6-9 \\
\mathrm{Sr}=31-34(32.2) & \mathrm{Sp}=32-33
\end{array}
$$

Winter flounder catches in depths greater than 69 fath were negligible (Table 1). It was not recorded from the northeastern part of the shelf, the major catches being in Div. $4 \mathrm{~W}(48 \%)$ and the Bay of Fundy $(34 \%)$.

Winter flounder is widely distributed in the Bay of Fundy and in coastal waters of Nova Scotia, but the only significant concentration on the shelf is located in shallow water on Sable Island Bank (Scott, 1976) although it occurs on Browns and Banquereau banks. It exhibits seasonal movements to and from deeper water (McCracken, 1963), and its distribution is presumably limited by both depth and temperature to relatively warm shallow-water areas where the bottom is suitable.

\section{Winter skate, Raja ocellata Mitchill 1815}

$$
\begin{aligned}
& \text { Dr }=15-200+(40.2) \\
& D p=20-49 \\
& \mathrm{Tr}=2-12(7.5) \\
& \mathrm{Sr}=31-34(32.5) \\
& T p=5-9 \\
& S p=32-34
\end{aligned}
$$

Winter skate occurred over the entire depth range sampled but $80 \%$ of the catches were from 20 to 49 fath (Table 1). It tended to occur in shallower water in the Bay of Fundy (20-49 fath) and on the northeastern part of the shelf (20-29 fath) than in the southwestern part (Table 2), but preferred temperature ranges and means were lower in the northeast and increased steadily toward the southwest.

The main concentrations of winter skate are found on the central and northeastern banks of the shelf, with minor concentrations in the southwestern area and in the Bay of Fundy (Scott, 1976).

Witch flounder, Glyptocephalus cynoglossus (Linnaeus 1758)

$$
\begin{array}{ll}
\mathrm{Dr}=15-200+(95.9) & \mathrm{Dp}=80-89 \\
\mathrm{Tr}=0-13(5.6) & \mathrm{Tp}=5-7 \\
\mathrm{Sr}=31-34(33.5) & \mathrm{Sp}=32-34
\end{array}
$$

Witch flounder was fairly evenly distributed throughout the depth range studied but tended to be 
more prevalent in depths of 70-199 fath, where $65 \%$ of the catches were recorded (Table 1), and the overall temperature and salinity ranges were also correspondingly wide. Preferred depth ranges and means indicated considerably deeper distribution on the shelf than in the Bay of Fundy (Table 2). Preferred temperatures showed a general increase from northeast to southwest, but salinities showed little change by area except for a considerable decrease in the Bay of Fundy.

Witch flounder is widely distributed in all depths on the shelf and in the Bay of Fundy, with major concentrations in the Bay of Fundy and on the northeastern part of the shelf, especially along the edge of the Laurentian Channel (Scott, 1976).

\section{Yellowtail flounder, Limanda ferruginea (Storer 1839)}

$$
\begin{aligned}
& \mathrm{Dr}=15-199(34.4) \\
& \mathrm{Tr}=1-12(5.2) \\
& \mathrm{Sr}=31-34
\end{aligned}
$$

$$
\begin{aligned}
& D p=20-49 \\
& T p=2-6 \\
& S p=32-33
\end{aligned}
$$

The depth range for this flounder was extensive, but $91 \%$ of the catches were made in depths less than 50 fath (Table 1). The temperature and salinity ranges were similarly wide, but $78 \%$ of the catches were recorded where temperatures were less than $7^{\circ} \mathrm{C}$ and $87 \%$ where salinities were in the $32-33 \%$ range. There was little change in preferred and mean depths along the shelf except in Div. $4 \mathrm{X}$ where the mean depth of occurrence was higher than in other areas (Table 2). Preferred and mean temperatures and salinities increased from northeast to southwest on the shelf, but, whereas the mean temperature was notably higher in the Bay of Fundy than in Div. 4X, the mean salinity was considerably lower.

Concentrations of yellowtail flounder occur mainly in the central and northeastern parts of the shelf, particularly the latter (Scott, 1976). It is the typical flatfish of the shallow-water banks there, being associated with the longhorn sculpin and winter skate. It is tolerant of low water temperatures and, despite its wide range, depth appears to be the major determinant of its distribution.

\section{Discussion}

Arranging the fishes in order of increasing mean depth of occurrence (Fig. 3) shows that there is a general tendency for some of the shallow-water species to have more restricted depth ranges and better defined preferred depth ranges than the deeper-water species. in particular, winter flounder, northern sand lance and little skate were restricted to depths less than 80 fath $(146 \mathrm{~m})$ with preferred ranges in depths less than 50

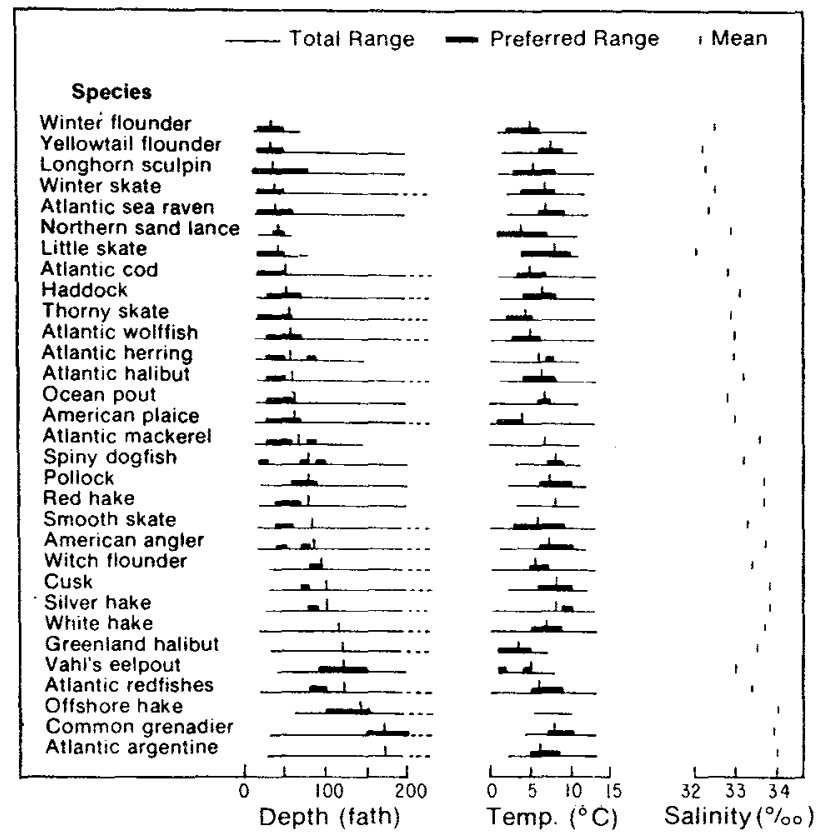

Fig. 3. Total and preferred ranges and means of depth and temperature and mean salinity for common fishes on the Scotian Shelf in summer. (Dashed line indicates extension beyond 200 fath.)

fath $(92 \mathrm{~m})$. In comparison, the distribution of most of the species in the lower part of the series (Fig. 3) extended over the entire range of depths examined.

The erratic temperature series in relation to increasing depth shows little correspondence between depth and temperature occurrence of the various species, due possibly to the unusual hydrographic regime. The characteristic temperature profile in summer shows a warm surface layer, a cold intermediate layer, and increasing temperature with depth below the cold layer (Hachey, 1942). Increasing or decreasing preferred depths are not matched to steadily changing temperatures, and therefore, there is no single relationship between the two.

The salinity series, however, shows a general increasing trend with increasing depth, as would be expected, because there is a progressive increase in salinity from the warm low-salinity surface water of the shelf, through the more saline cold intermediate layer, to the warm saline water along the slopes.

There are some obvious anomalies in the salinity distributions (Fig. 3). The mean values for little skate, ocean pout and Vahl's eelpout tend to be out of phase with the trend. Little skate and ocean pout are found mostly in the Bay of Fundy area with its comparatively low salinity-depth relationship which explains their position. However, Vahl's eelpout is concentrated in moderately deep water on the northeastern and central parts of the shelf, and the comparatively low salinity 
and temperature preferences combined (Fig. 3) may result from its concentration in areas affected by the cold intermediate water, although its preferred depth range disputes this possibility.

Typically, preferred and mean temperatures show a decrease from southwest to northeast along the shelf for the major demersal species examined (Table 2). This corresponds to the general decrease in bottom temperatures, noted by McLellan (1954), and implies that the fish may seek uniform depth, salinity, or some other factors besides temperature. The geographical area-depth relationships are variable (Table 2 ), and in only a few cases is there a uniform trend that indicates some relationship between the two factors. The evidence indicates that there is no single abiotic controlling influence. Other factors such as food availability, bottom type and seasonal migration, all interrelated with physical factors, must also play their part.

Comparison of preferred depth and temperature ranges and mean salinity within selected groups of related fishes of major importance on the Scotian Shelf provides evidence of niche diversity at the species level (Fig. 4). In the gadoids, there is considerable overlap in preferred depths, but a progression from shallow to deep water is clearly evident, except for the rare offshore hake which is usually caught with silver hake in deep water along the edge of the shelf. The temperature data show little distinction between the species, but the salinity data separate cod and haddock as two low-salinity gadoids from the remaining species which exhibit salinity preferences in a narrow band at the upper part of the scale.

In the flatfishes, there is little in the preferred depth distributions to distinguish the species, except for the witch flounder and Greenland halibut which form a deep-water group, but there is a gradation in salinity preferences (Fig. 4). Temperature preferences indicate two groups: cold-water yellow flounder, American plaice and Greenland halibut, and warm-water winter flounder, Atlantic halibut and witch flounder. There is no obvious association between depth and temperature distributions of the species. The distinction between winter flounder and yellowtail flounder probably derives from differential geographical distribution, catches of the former being more prevalent in the less saline, warm waters of the Bay of Fundy and catches of the latter on the northeastern part of the shelf.

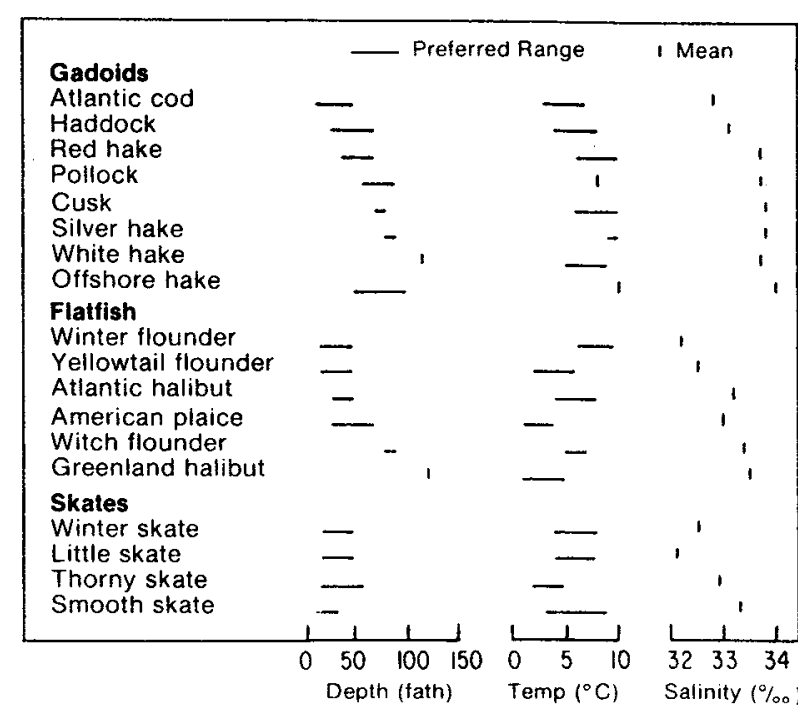

Fig. 4. Preferred depths and temperatures and mean salinity for selected demersal fishes of related fish groups on the Scotian Shelf in summer.

The skates exhibit wide overlap in depth and temperature preferences but a clear distinction in salinities (Fig. 4). The association of high salinity and low preferred depth in smooth skate is anomalous and not readily explained by its geographical distribution, with main concentrations along the edge of the Laurentian Channel and in the Bay of Fundy (Scott, 1976).

\section{References}

BIGELOW, H. B., and W. C. SCHROEDER. 1953. Fishes of the Gulf of Maine. Fish. Bull, U. S., 53, 577 p.

COLTON, J. B. 1972. Temperature trends and the distribution of groundfish in continental shelf waters, Nova Scotia to Long Island. Fish. Bull., U. S., 70; 637-657.

COUTANT, C. C. 1977. Compilation of temperature preference data. $J$. Fish. Res. Bd. Canada, 34; 739-745.

HACHEY, H. B. 1942. The waters of the Scotian Shelf. J. Fish. Res. Bd. Canada, 5: 377-397.

HALLIDAY, R. G., and A. C. KOHLER. MS 1971. Groundfish survey programmes of the St. Andrews Biological Station, Fisheries Research Board of Canada - objectives and characteristics. ICNAF Res. Doc., No. 35, Serial No. 2520.

LEIM, A. H., and W. B. SCOTT. 1966. Fishes of the Atlantic coast of Canada. Bull. Fish. Res. Bd. Canada, 155, 485 p.

MCCRACKEN, F. D. 1963. Seasonal movements of the winter flounder Pseudopleuronectes americanus (Walbaum), on the Atlantic coast. J. Fish. Res. Bd. Canada, 20; 551-586.

MCLELLAN, H.J. 1954. Bottom temperatures on the Scotian Shelf. J. Fish. Res. Bd. Canada, 11; 404-418.

SCOTT, J. S. 1976. Summer distribution of groundfish on the Scotian Shelf, 1970-74. Fish. Mar. Serv. Canada, Tech. Rep., 635, 12 p. 
